\title{
WATER FOR ALL? DEVELOPING A HUMAN RIGHT TO WATER IN NATIONAL AND INTERNATIONAL LAW
}

\author{
The Rt Hon Lady Justice Arden*
}

Human rights are one of the great ideas of the twentieth century. After World War II, first Eleanor Roosevelt in relation to the Universal Declaration of Human Rights ('the Universal Declaration'), ${ }^{1}$ and then later the drafters of the European Convention on Human Rights ('the European Convention') saw human rights as the way to make the world fairer and safer. ${ }^{2}$

However, the Universal Declaration and the European Convention are first generation human rights instruments. They also focus on civil and political rights and neither provides for a right to water. Yet there is nothing more fundamental to human life than water. We all need it. There is no substitute for it. There is a limited amount of it. The developed world is using the lion's share of it. We do not just need clean water to drink; we need it for sanitation, to grow crops and as a habitat for fish to eat. We need safe water to prevent waterborne diseases.

As many areas of the world are experiencing a shortage of water, and humans are having to compete with industry, we need to find ways of expressing the idea of water for all and there is no better way to achieve this than through the avenue of human rights law. The world is becoming increasingly industrialized, and industrial processes need vast amounts of water (for instance, it takes about 45 litres of water to produce a glass of beer and about 140 litres to produce a cup of coffee). ${ }^{3}$ Industrial processes can also pollute water and that pollution can lead to degradation of the living environment for humans and permanent change in the physical environment.

* Lady Justice Arden is a member of the Court of Appeal of England and Wales and Head of International Judicial Relations for England and Wales. She would like to thank Dalton Hale, her Judicial Assistant for his assistance in preparing this lecture, and Professor Mads Andenas, Professor of Law at the University of Oslo and VV Veeder QC for their helpful comments. The faults, however, remain the author's. Lady Justice Arden also wishes to thank the following for assistance in locating materials: Sam Bryan, Royal Courts of Justice Library, Gemma Ralph, Foreign and Commonwealth Office, Geneviève Woods, European Court of Human Rights Library and Tiffani Willis, Research Services Librarian, Pepperdine University School of Law, California, USA. Editorial assistance was provided by Richard Mackenzie-Gray Scott.

1 Universal Declaration of Human Rights (adopted 10 December 1948) UNGA Res 217 A(III).

${ }^{2}$ Council of Europe, European Convention for the Protection of Human Rights and Fundamental Freedoms, as amended by Protocols Nos 11 and 14 (4 November 1950) ETS 5.

${ }^{3}$ T Allan, Virtual Water: Tackling the Threat to Our Planet's Most Precious Resource (IB Tauris 2011); AK Chapagain and AY Hoekstra, The Water Needed to Have the Dutch Drink Tea (UNESCO-IHE 2003) 21. 
The human right to water is an idea whose time has come. The argument presented here is that, with industrialization and climate change, it is increasingly necessary to have a principle of law that everyone is entitled to a minimum amount of safe water for drinking, sanitation and growing food: an acceptable minimum water ration.

The right to a decent minimum water ration needs to be developed both nationally and internationally to do what human rights law was always intended to do: to ensure happiness, peace and prosperity- to adopt what Winston Churchill, who proposed a European Charter of Rights in 1947, said: 'To jawjaw always is better than to war-war'. ${ }^{4}$ Human rights discourse enables problems to be sorted out in a peaceful fashion. The human right to water must surely be an uncontroversial human right, even for the originalists who take the view that the only human rights are those that were already recognized in $1950 .^{5}$

\section{Statistics}

The statistics and projections about the shortage of water are terrifying. The UN states that there is a risk that within 30 years one in four people is likely to live in a country affected by chronic or recurring shortages of fresh water. ${ }^{6}$ According to WaterAid, $650 \mathrm{~m}$ people live without safe water, ${ }^{7}$ one in three people does not have access to proper sanitation and 900 children a day die from diarrhoeal diseases caused by dirty water and poor sanitation. ${ }^{8}$ Across the world, women walk long distances to collect what is often dirty water. ${ }^{9}$

As water shortages increase, water will drive international relations. ${ }^{10}$ About 27,000 of the 50,000 rivers in China have disappeared since the $1950 \mathrm{ss}^{11}$ The mighty rivers such as the Yellow River, the Yangtze and the Mekong rise in Tibet and this may be one of the reasons for China's interest there. ${ }^{12}$ China has had to dam its great rivers to have enough water to serve its people and service its industries. ${ }^{13}$ However, dams inevitably mean that other countries

${ }^{4}$ R Langworth, The Definitive Wit of Winston Churchill (Public Affairs 2009) 37: 'On 30 January 1958 Harold Macmillan, speaking in Canberra, echoed Churchill's words with the phrase (frequently but wrongly attributed to Churchill himself), "Jaw, jaw is better than war, war".'

5 For reasons of time and space, I must leave out of account international law dealing with watercourses and access to water in armed conflict.

${ }^{6}$ UN Sustainable Development Goals, 'Goal 6: Ensure access to water and sanitation for all' $<$ http://www.un.org/sustainabledevelopment/water-and-sanitation/>.

7 Water Aid, 'The Crisis' <http://www.wateraid.org/uk/what-we-do/the-crisis $>. \quad{ }^{8}$ ibid.

9 ibid.

10 C Harrington, 'Fluid Identities: Toward a Critical Security of Water' (2013) Electronic Thesis and Dissertation Repository Paper 1716, $60<$ http://ir.lib.uwo.ca/cgi/viewcontent.cgi?article= 2884\& context $=$ etd $>$.

11 A Hsu and W Miao, '28,000 Rivers Disappeared in China: What Happened?' (The Atlantic, 29 April 2013) <http://www.theatlantic.com/china/archive/2013/04/28-000-rivers-disappeared-inchina-what-happened $/ 275365 />$.

${ }^{12}$ C Lewis, 'China's Great Dam Boom: A Major Assault on Its Rivers' (Yale Environment 360, 4 November 2013) <http://e360.yale.edu/feature/chinas_great_dam_boom_an_assault_on_its_ river_systems/2706/>.

${ }^{13}$ See, for example, the current South-North Water Diversion Project, which is estimated to cost 50 billion GBP. 
may have less water. Moreover, sometimes the unforeseen happens when you interfere with nature - desertification is now only 13 miles from Beijing ${ }^{14}$ and is affecting many other countries too. ${ }^{15}$

This article considers, first, how domestic law and constitutional law have developed the right to water. Next it considers how supranational courts have harnessed other human rights, such as the right to life, so as to ensure a minimum water ration for people. It then discusses the difficulties for the law in allocating water, before finally looking at current global initiatives which march in step with a human right to water.

\section{THE NATIONAL LEVEL}

\section{A. The Common Law's Approach to Disputes about Entitlement to Water: A Complex Picture}

I recently published a book called Common Law and Modern Society - Keeping Pace with Change. ${ }^{16}$ The basic message is about the role of judges and others in keeping the law up to date. The book started with a chapter entitled 'Water Matters'; I was inspired to write on this subject by the work I was engaged with in the Court of Appeal. It had come as a surprise to find that there was a regular diet of cases that for one reason or another involved the law of water. I therefore decided to study the law of water and found it both fascinating and complex. Fortunately the United Kingdom (UK) and Ireland seem to have plenty of water: it is so plentiful in Ireland that it was provided free until 2014, when a water rate was introduced against considerable opposition. ${ }^{17}$ In the UK the problem of not having the decent minimum water ration has arisen infrequently in the last few decades. However, there have been other problems over the centuries and it has been fascinating to find that many problems of international law have already occurred in the domestic context.

The following are some examples. With the industrialization of the UK in the late eighteenth and early nineteenth centuries, there were cases of disputes between upstream and downstream landowners, arising out of what the downstream landowner saw as excessive use by the upstream owner- and in some cases the creation of upstream dams. I give in my book the examples of Bealey $v$ Shaw ${ }^{18}$ and Williams $v$ Morland. ${ }^{19}$

14 LR Brown, J Larsen and B Fischlowitz-Roberts, The Earth Policy Reader (Earthscan 2003) 12.

15 E King, 'Desertification crisis affecting 168 countries worldwide' (Climate Home, 17 April

2013) < http://www.climatechangenews.com/2013/04/17/desertification-crisis-affecting-168countries-worldwide/ $>$.

${ }_{16}$ M Arden, Common Law and Modern Society - Keeping Pace with Change (Oxford University Press 2015).

17 S Harrison, 'Irish Water: How the Dublin government are struggling with water charges' (BBC News, 30 October 2014) <http://www.bbc.co.uk/news/world-europe-29798331>.

18 Bealey v Shaw (1805) 102 ER 1266 (KB). $\quad 19$ Williams v Morland (1824) 107 ER 620. 
In Bealey $v$ Shaw, two mill owners disputed the use of water in the River Irwell. The downstream plaintiff complained that the upstream defendant was diverting more water to his mill than he had done previously, thereby depriving the plaintiff of the flow that he was used to for the purposes of using his own mill. The four judges found in favour of the plaintiff, and two did so on the basis of a pure adherence to the appropriation doctrine. Under this doctrine, where an upstream user had hitherto left water unappropriated, that water was available to be appropriated by successive downstream users. If the upstream user then increased the amount of water that he appropriated, he thereby interfered with the established first appropriation of those below him. That gave rise to an actionable wrong.

I then compared Williams $v$ Morland, where the plaintiff, the downstream user, complained that he had lost the benefit and advantage of a stream on his land since the defendant had built a dam upstream, but he could not establish any past pattern of appropriation. The issue for the Court was whether the plaintiff could simply complain of an interrupted flow without showing some use had been interfered with. The Court held that he had to show some injury to the existing appropriation of the water flow. It was not sufficient simply to say that the flow had been disrupted.

Later the courts developed the natural rights theory. This viewed water as a natural resource and did not depend on the riparian owner having previously put the water to use. The courts were partly influenced by the idea that water was res communes ie that water was residually owned by the public. An example of natural rights theory was Miner $v$ Gilmour. ${ }^{20}$ Here the plaintiff complained that the defendant had diverted flow away from the plaintiff's tannery to the defendant's mill. The defendant's defence was that the plaintiff had known about the mill before he bought his property and thus could not complain about it. The Privy Council held that reasonable use for domestic purposes or irrigation could not give rise to an action even if it caused actual damage to the plaintiff. Use for any other purpose was permitted provided it did not interfere with the rights of other riparian owners. The Privy Council held that the owner of the tannery could not establish a right to the flow of water to the prejudice of the owner of the mill. On the facts the defendant's use of the water for his mill was reasonable, given that it was long-standing, and accordingly damage to the plaintiff was not actionable.

Thus the two requirements for an action were (1) an unreasonable use of the water by the defendant; and (2) a material interference with the plaintiff's right to reasonable use himself. The theory of natural rights is important in the international context as two States enjoying a single source of water may develop their water needs at a different pace. The natural rights theory allows for that to a greater extent than appropriation theory, and it entails a balancing of rights.

${ }^{20}$ Miner v Gilmour (1858) 14 ER 861 (PC). 
The great case of Bradford Corporation v Pickles also ${ }^{21}$ concerns this area of law. Mr Pickles (to the annoyance of Bradford Corporation) intercepted subterranean percolating water, ie groundwater, which the fast-expanding city of Bradford needed for its inhabitants. Since it was not part of a defined stream, this water was not res communes and, since it was on his land, Mr Pickles could do with it as he wished. That is why Lord Macnaghten spoke those oft-quoted words:

If the act, apart from motive, gives rise merely to damage without legal injury, the motive, however reprehensible it may be, will not supply that element. ${ }^{22}$

That is the conventional common law approach. However, the human rights law narrative now gives us the obvious framework to use where the issue relates to the decent minimum water ration for communities or individuals.

\section{B. National Courts Develop a Constitutional Right to Water}

\section{India}

India pioneered the right to water, its courts being the first to recognize a right to safe water. India's Constitution does not contain explicit recognition of the right to water. However, its courts have for some time interpreted the right to life in Article 21 of the Constitution as including the right to a healthy environment, which itself includes the right to pollution-free water. ${ }^{23}$

In Rural Litigation and Entitlement Kendra Dehradun $v$ State of Uttar Pradesh, which was also known as the 'Doon Valley case', a dispute arose over mining which was causing considerable environmental damage. The Supreme Court, after much investigation, ordered that the mining work should stop. It held that:

The consequence of this order made by us would be that the lessees of limestone quarries would be thrown out of business. This would undoubtedly cause hardship to [the lessees], but it is a price that has to be paid for protecting and safeguarding the right of the people to live in a healthy environment with minimal disturbance of ecological balance and without avoidable hazard to them, to their cattle, homes and agricultural land and undue affection of air, water and environment. ${ }^{24}$

Subsequently, in Vellore Citizens Welfare Forum v Union of India ${ }^{25}$ and S.K. Garg $v$ State of Uttar Pradesh and Ors, ${ }^{26}$ the Supreme Court of India held that remediation of the damaged environment is part of the principle of sustainable development and that the polluter was liable to pay compensation to the individuals who suffered, as well as the cost of reversing the damaged ecology.

21 Bradford Corporation v Pickles [1895] AC 587.

22 ibid [601].

23 BL Wadhera v Union of India (1996) AIR 1996 SC 2969; Indian Council for Enviro-Legal Action v Union of India (1996) AIR 1996 SC 1446 [55] and [65].

${ }^{24}$ Rural Litigation and Entitlement Kendra Dehradun v State of U.P. \& Ors (1985) AIR 1985 SCR 652.

25 Vellore Citizens Welfare Forum v Union of India (1996) AIR 2715.

26 S.K. Garg v State of Uttar Pradesh and Ors (1999) AIR All 41. 
The Supreme Court of India has attempted to maintain the balance between ecology and development. In Mehta $v$ Union of India ${ }^{27}$ it held that groundwater was a social asset and that priority had to be given to domestic and agricultural uses over industrial uses. They did not, therefore, apply the approach in Bradford Corporation v Pickles. The Supreme Court also held that water is communal property (res communes) held in public trust by the State:

[t]he state as a trustee is under a legal duty to protect natural resources. These resources meant for public use cannot be converted into private ownership.

The Supreme Court has gone on to develop that concept of public trust to buttress the right to water, but that jurisprudence is outside the scope of this article. In India mismanagement of water resources continues and has given rise to what has been described as 'water wars'. ${ }^{28}$ Despite the positive steps taken by the legal profession in India, there is still much work left to be done in order to ensure safe water for all people.

\section{South Africa}

South Africa is one of the few countries whose constitution protects the right to water. ${ }^{29}$ It has to cope with vast water problems principally for two reasons. First, water is scarce: indeed many parts of South Africa are currently experiencing a severe drought. ${ }^{30}$ Second, one legacy of the apartheid era is that access to water supply is extremely unevenly distributed. ${ }^{31}$ Under the Constitution, the State does not have an absolute obligation to provide the decent minimum water ration. The right is one which requires the State to act reasonably within its resources. Thus section 27 of its constitution provides:

(1) Everyone has the right to have access to ... sufficient food and water.

(2) The state must take reasonable legislative and other measures, within its available resources, to achieve the progressive realisation of [this right].

An example of section 27 in practice is Residents of Bon Vista Mansions $v$ Southern Metropolitan Local Council. ${ }^{32}$ The residents launched an urgent

${ }^{27}$ Mehta $v$ Union of India (2004) 12 SCC 118; See also Narmada Bachao Andolan v Union of India (2000) 10 SCC 664, where the government was permitted to construct 3,000 dams of differing sizes on the Narmada River, but the Supreme Court reaffirmed the right to water.

28 V Mallet, 'India: Water Wars' (Financial Times, 13 April 2016) < http://www.ft.com/cms/s/0/ 96687242-009b-11e6-ac98-3c15a1aa2e62.html\#axzz46G1B3iTj>.

${ }^{29}$ Constitution of South Africa (adopted 8 May 1996, amended 11 October 1996) arts 25(8) and 27.

$30<$ http://www.bbc.co.uk/news/world-africa-34884135>.

31 N Funke, K Nortje, K Findlater, M Burns, A Turton, A Weaver and Hanlie Hattingh, 'Redressing Inequality: South Africa's New Water Policy' (Environment Magazine, April 2007) $<$ http://www.environmentmagazine.org/archives/back\%20issues/april\%202007/funke-full.html>.

32 Residents of Bon Vista Mansions v Southern Metropolitan Local Council (2002) High Court, Witswatersrand Local Division: 6 BCLR 625 (W). 
application in the High Court for interim relief because the local council had disconnected their water supply. The High Court held that the matter involved the State's duty with respect to access to water. The High Court also held that, in order to apply section 27(1)(b) of the South African Constitution, it had, as required by section 39(1)(b) of that Constitution, to have regard to international law. The High Court paid particular regard to the International Covenant on Economic, Cultural and Social Rights of 1966 ('ICESCR') ${ }^{33}$ and noted that both instruments used similar language. It concluded that the constitutional duty must be understood in the same way as duties under the ICESCR, namely that the State must refrain from actions that would deprive individuals of their rights. The High Court found that the applicants had access to water before the council disconnected the supply, and that the conditions and procedures for disconnection had not been 'fair and equitable' in accordance with section 4(3) of the South African Water Services Act 108 (1997), since reasonable notice of termination and the opportunity to make representations had not been provided. The opportunity to make representations required by section 4(3)(c) of that Act allowed a person to prove that he could not afford to pay. The High Court accordingly found that the council's disconnection of an existing water supply to consumers constituted prima facie a breach of its constitutional duty to respect the right of existing access to water and that the applicants had satisfied the requirements for granting relief. ${ }^{34}$

\section{SUPRANATIONAL COURTS DEVELOP RIGHTS TO WATER FROM OTHER HUMAN RIGHTS}

Supranational courts responsible for human rights in their region have also responded to the right to water issue. They have developed a human right to water even where this is not conferred by their founding instrument. As is well known, the European Convention contains a right to life (Article 2), ${ }^{35}$ a

\footnotetext{
33 International Covenant on Economic, Social and Cultural Rights (adopted 16 December 1966, entered into force 3 January 1976) 993 UNTS 3.

34 The right to water is also explicitly recognized in other national constitutions: see, for example, the constitutions of Ethiopia, Uruguay, Ecuador and Bolivia. Other Constitutions recognize other rights from which the right to water can be derived, including the constitution of Turkey: see Taskin v Turkey App No $46117 / 99$ (ECtHR, 10 November 2004).

35 Article 2 of the European Convention provides: Right to life:
}

1. Everyone's right to life shall be protected by law. No one shall be deprived of his life intentionally save in the execution of a sentence of a court following his conviction of a crime for which this penalty is provided by law.

2. Deprivation of life shall not be regarded as inflicted in contravention of this Article when it results from the use of force which is no more than absolutely necessary:
(a) in defence of any person from unlawful violence;
(b) in order to effect a lawful arrest or to prevent the escape of a person lawfully detained;
(c) in action lawfully taken for the purpose of quelling a riot or insurrection. 
right not to be subjected to inhuman treatment (Article 3), ${ }^{36}$ and a right to respect for private and family life (Article 8). ${ }^{37}$ The European Court of Human Rights ('ECtHR') has developed its case law so that the right to private life includes the right to an acceptable living environment. ${ }^{38}$ It has done this by using the 'living instrument' approach to interpretation. If it were appropriate to do so, the ECtHR might develop these rights further so as to impose a positive obligation on States to ensure a healthy environment and sufficient clean water to meet the decent minimum water ration.

The best-known judgment of the ECtHR in this area is López Ostra v Spain. ${ }^{39}$ In that case, the ECtHR held that there was a violation of Article 8 of the European Convention where the State had allowed a waste treatment plant to operate and cause smells, noise and polluting fumes a few metres away from the applicant's family's home with serious effects on, and risks to, their health. The Court held that the result would be the same whether the question was analysed in terms of a positive duty on the State to take reasonable and appropriate measures to secure the applicant's rights under Article 8(1), or in the terms of an 'interference by a public authority' to be justified in accordance with Article 8(2). The ECtHR therefore left open the possibility that it would develop a positive duty to secure a healthy environment.

The Court of Appeal of England and Wales relied on this line of authority in Marcic v Thomas Water Utilities Ltd ${ }^{40}$ to provide Mr Marcic with a remedy when his home was regularly flooded by effluent, which the water authority had decided it could not economically prevent. But the House of Lords overruled this decision on the basis that Parliament had provided other remedies for this situation. ${ }^{41}$

The European Convention usually only applies if the wrongdoer is a State or embodiment or agent of the State. But the State may still be liable even where the wrongdoer is a private sector organization if it can be said that the State

\footnotetext{
36 Article 3 of the European Convention provides:

Prohibition of torture

No-one shall be subjected to torture or to inhuman or degrading treatment or punishment.

37 Article 8 provides:

Right to respect for private and family life
}

1. Everyone has the right to respect for his private and family life, his home and his correspondence.

2. There shall be no interference by a public authority with the exercise of this right except such as is in accordance with the law and is necessary in a democratic society in the interests of national security, public safety or the economic well-being of the country, for the prevention of disorder or crime, for the protection of health or morals, or for the protection of the rights and freedoms of others.

38 Guerra and Others v Italy App No 116/1996/735/932 (ECtHR, 19 February 1998); Mcginley and Egan $v$ The United Kingdom App No 10/1997/794/995-996 (ECtHR, 9 June 1998).

39 López Ostra $v$ Spain App No 16798/90 (ECtHR, 9 December 1994).

40 Marcic v Thomas Water Utilities Ltd [2002] QB 929.

41 Marcic v Thomas Water Utilities Ltd [2002] 2 AC 42. 
failed to regulate the polluter as it should have done. López Ostra is an example of a case where that happened. ${ }^{42}$ The ECtHR, in a creative use of European Convention rights to protect environmental rights, has also imposed positive obligations on the State to provide information to tell people about environmental risks where they live, for example about the risks involved in carrying out some new industrial process in their area. ${ }^{43}$ It also protects the right to freedom of expression and the right to free association so that people can meet and speak about environmental risks. This encourages proper democratic decision-making in a State.

The Inter-American Human Rights Court ('IAHRC') has developed the right to personal integrity and the right not to be subjected to inhuman treatment in the American Convention on Human Rights ('ACHR') in cases concerning prisoners so as to make it a violation of those rights not to provide prisoners with sufficient, safe drinking water. ${ }^{44}$

The IAHRC has also interpreted these rights in favour of landless indigenous people in Paraguay who were encamped near their ancestral lands, from which they had been evicted, when they had no access to clean water (other than rainwater). ${ }^{45}$ The IAHRC has also relied on the right to life, ${ }^{46}$ holding that there was not just a negative obligation not to deprive a person of his life but also a positive obligation (where the State knows there is a risk to life) to prevent conditions arising which impede a decent minimum existence. ${ }^{47}$

When interpreting the AHRC, the IAHRC uses a living instrument approach similar to that which the ECtHR uses in relation to the European Convention. In addition, like the ECtHR, the IAHRC works out the current content of a right guaranteed by the ACHR by reference to international standards. Accordingly, the IAHRC has interpreted those rights by reference to General Comment 15, to which I refer below. ${ }^{48}$

\section{PRACTICAL DIFFICULTY OF ESTABLISHING PRIORITIES IN WATER ALLOCATION}

If there is a human right to a decent minimum water ration, it will be a huge task to work out what each individual human being in any particular situation should

42 See above (n 39).

43 McGinley and Egan $v$ The United Kingdom App No 10/1997/794/995-996 (ECtHR, 9 June 1998).

44 See, for example, IACHR López Alvarez v Honduras (2006) Series C No 141.

45 JM Chavarro, 'The Emergence of the Right to Water in the Inter-American Court of Human Rights' (2015) 8 Inter-American and European Human Rights Journal 95.

46 IAHRC, art 4.

47 See, for example, IACHR Indigenous Community Sawhoyamaxa v Paraguay (2006) Series C No 146.

${ }^{48}$ For the sake of completeness, it should also be mentioned that there are other regional courts which have recognized the right to water, including the African Commission on Human and People's Rights. In 1997, for example, this Commission held Nigeria to be in breach of its obligations under the African Charter of Human and Peoples' Rights for allowing the contamination of the water resources in Ogoniland. F Coomans, 'The Ogoni Case before the African Commission on Human and Peoples’ Rights’ (2003) 52 ICLQ 749. 
have. The common law doctrines of appropriation and natural rights are not apt for this task because they do not assist in the allocation of water to persons other than riparian owners. In addition, the demand for water may change over time. In addition, it is likely to be difficult to compare and assess the value of the benefit of the water for different purposes, which might even require a payment by the one party to another.

At the end of Water Matters, I cite a passage from an article written by Professor Lon Fuller of Harvard Law School in which he notes that over the ages there has been a great diversity of legal rules affecting irrigation water. He writes:

In actual practice, over the world and through history, the most diverse rules had been applied to the allocation of irrigation water. These rules expressed every conceivable standard of distributive justice first come, come, first served [appropriation theory and Islamic law]; to each according to his contribution [Near East]; to each according to his needs [Persia]; to each according to the needs of society [Persia and Egypt]; to each according to the luck of the throw [British colonial laws in India]. ${ }^{49}$

Similar difficulties exist in relation to transboundary rivers, that is, rivers which have their source in one State but flow through other States. They may drain in yet another State. The States where the rivers drain are likely to be in the best position to control the waters of a river. Other States can only control the flow of the river as it passes through their State and their activities can affect the quality and the quantity of water that flows to other States. In the absence of some specific treaty or convention, the rights in international law of the various States are unclear. However, the Convention on the Protection and Use of Transboundary Watercourses and International Lakes imposes obligations and confers rights on States which are party to that Convention. ${ }^{50}$ These rights primarily concern water quality and include not being subject to water pollution originating in another State, having relevant information regarding water sources exchanged between States and being warned of water-based dangers with a transboundary impact. ${ }^{51}$ Where treaties and conventions do not apply, there is a substantial body of opinion in international law that no State is bound to act in the interests of any other State which is a riparian

49 LH Fuller, 'Irrigation and Tyranny' (1965) 17 SLR 1021; See also BN Cardozo, The Growth of the Law (Yale University Press 1924) 118-19, who explains that the arid American states reverted to appropriation theory because of their particular circumstances.

50 See also S McCaffrey, 'Some Developments in the Law of International Watercourses' in M Kohen (ed), Promoting Justice, Human Rights and Conflict Resolution through International Law (Martinus Nijhoff 2007) 785; S McCaffrey, The Law of International Watercourses: NonNavigational Uses (2nd edn, OUP 2007).

${ }^{51}$ Convention on the Protection and Use of Transboundary Watercourses and International Lakes (adopted 17 March 1992, entered into force 6 October 1996) 1936 UNTS 269. See also the Convention on the Law of the Non-Navigational Uses of International Watercourses (adopted 21 May 1997, entered into force 17 August 2014), which is more concerned with water allocation than the 1992 Convention. 
owner. ${ }^{52}$ In other words, a State is often regarded as having absolute sovereignty over the waters within its jurisdiction. On the other hand, there is some distinguished support for the theory that a State may not alter the course of transboundary rivers within its territory. The truth may lie somewhere between these two positions.

Sometimes States can agree to share the benefits of a river. However, that may be difficult in the case of rivers, like the Mekong River, where countries are at different stages of development or have different needs. One may want to have a hydroelectric power station while the other may want water for irrigation, or one may want to build factories and have golf clubs, and the other to grow rice.

In this situation there has to be some system for deciding between competing needs. Some help here may be obtained from the case law of the Supreme Court of the United States. Over the years the Court has been called upon to decide disputes between US states regarding the allocation of water from rivers running through more than one state. In deciding these disputes, the Supreme Court of the United States is in a similar position to that which an international court would be in if it was deciding an issue of water allocation between different countries or communities. Where there are competing needs for water, the Supreme Court of the United States applies its equitable utilization doctrine. ${ }^{53}$

Kansas $v$ Colorado ${ }^{54}$ illustrates how the Supreme Court of the United States applies its doctrine of equitable utilization. Kansas sued to prevent Colorado from diverting the waters of the Arkansas River. This rises in Colorado but flows into Kansas, whose name suggests it ought to have substantial benefit from it. The Supreme Court proceeded with a detailed analysis of Colorado's use of the river. It examined data showing significant agricultural development of land in Colorado's portion of the river basin, and Colorado's dependence upon this source of water for irrigation. The Supreme Court then examined the situation in Kansas. It found that south-western Kansas had suffered limited detriment in some agricultural areas as a result of the diversion; that population tables indicated that the diversions were not responsible for a decrease in population in the allegedly affected area; and that state-wide agricultural tables showed no marked injury to Kansas due to the diminution of the flow. The Supreme Court concluded:

[W] hen we compare the amount of this detriment with the great benefit which has obviously resulted to the counties in Colorado, it would seem that equality of right and equality between the two States forbids any interference with the present withdrawal of water in Colorado for the purposes of irrigation. ${ }^{55}$

52 C Mendis, 'Sovereignty vs. trans-boundary environmental harm: The evolving International law obligations and the Sethusamuduram Ship Channel Project' (2006) UN/Nippon Foundation Working Paper <http://www.un.org/depts/los/nippon/unnff_programme_home/fellows_pages/ fellows_papers/mendis_0607_sri_lanka.pdf $>$.

53 AH Garretson, RD Hayton and CJ Olmstead (eds), The Law of International Drainage Basins (Oceana Publications 1967).

54 Kansas v Colorado (1907) 206 US 46. 
It is clear that the Court went through a weighing and balancing process in reaching its decision. It is important to note that in general future use is not protected, as in Williams $v$ Morland..$^{56}$

However difficult it may be to allocate water resources, the law should be the only way to resolve these difficulties. Where there is competition between different countries or communities, it may be that the equitable utilization doctrine of the United States would be a useful starting point.

\section{DEVELOPING THE HUMAN RIGHT TO WATER AT THE INTERNATIONAL LEVEL}

\section{A. The Clash between the Concept of Water as an Economic Asset and Water as a Human Right}

A number of countries, particularly in South America, decided to privatize their water industry and they entered into agreements providing for arbitration if there was a dispute between the parties in accordance with the 1965 Convention on the Settlement of Investment Disputes between States and Nationals of Other States. ${ }^{57}$ This Convention is much used by States: Judge Bruno Simma of the International Court of Justice stated in his Grotius lecture in 2011 that there were then some 3,000 bilateral investment agreements in force involving some 170 countries. ${ }^{58}$ Under this Convention, there is the International Centre for the Settlement of Investment Disputes (ICSID). Disputes did happen. In particular, in one case concerning Argentina, the other party (Vivendi) argued that, by introducing restrictions on the amount by which Vivendi could increase water charges, Argentina prevented it from carrying out its side of the agreement to provide a supply of water, while Argentina argued that Vivendi had put up the prices so much that people could not afford them. ${ }^{59}$

Needless to say this was soon challenged as an interference with the right to water. In the case in question, the right was asserted on behalf of the citizens of the Province of Tucumán. An ICSID arbitration took place. Argentina lost. There is no right of appeal enabling a party to set aside an ICSID arbitration award but a party can seek an annulment of the award. So Argentina asked for the award in Vivendi's favour to be annulled. One of Argentina's grounds for an annulment was that the award 'disregarded fundamental issues related to the dispute ... between the parties relating to the right to water as essential human right $[\mathrm{s}]$...'. Unfortunately for Argentina, the annulment application failed. Remarkably there was no reference in the decision refusing an

\footnotetext{
56 See above (n 19).

57 Convention on the Settlement of Investment Disputes between States and Nationals of Other States (adopted 18 March 1965, entered into force 14 October 1966) 575 UNTS 159.

58 B Simma, 'Foreign Investment Arbitration: A Place for Human Rights?' (2011) 60 ICLQ 573.

59 Compañia de Aguas del Aconquija SA. and Vivendi Universal SA v Argentine Republic (ICSID case no ARB/97/3) (Original Proceeding) 21 November 2000.
} 
annulment to its human rights argument. ${ }^{60}$ The same happened in a number of similar awards. ${ }^{61}$

However, Judge Simma argues that, as a matter of policy, international investment arbitration and human rights are not 'separate worlds'. ${ }^{62} \mathrm{He}$ argues, among other things, that investment protection and compliance with obligations derived from internationally guaranteed economic and social rights may be capable of being balanced (though with difficulty) through interpretation of the agreement if the obligations of the State are subject to its international law obligations. He refers to newer forms of investment agreements that strike the balance between investment protection and the need for a State to meet other policy goals. ${ }^{63}$ Furthermore, there is now some evidence of ICSID awards being made which recognize the State's obligations to observe its human rights, but these awards do not enable the human rights obligation to trump investment protection obligations. ${ }^{64}$ They hold that the State must balance its two sets of obligations equally.

It is increasingly likely that human rights arguments will be advanced not only by States but also by third parties. In the past, arbitrators in ICSID arbitrations have rejected applications by NGOs and others to be joined to ICSID arbitrations in order to make representations about violations of human rights. However, consistently with the change in approach to human rights obligations, ICSID rules have since 10 April 2006 permitted arbitrators to approve the joinder of third parties if no party objects. ${ }^{65}$

\section{B. The Concept of Water as a Human Right Takes Root in International Law}

It was observed above that the first generation of human rights instruments, namely the Universal Declaration and the European Convention did not recognize the human right to water. Likewise the International Covenants of 1966, namely the International Covenant on Civil and Political Rights or the IESCR, did not recognize the human right to water. The 1979 Convention on the Elimination of All Forms of Discrimination against Women, Article 14(2) mentions the human right to water in that it requires States to ensure women adequate living conditions, including sanitation and the right to water. Likewise the International Convention on the Rights of the Child, Article 24 obliges States to recognize the child's right to health and to pursue

60 Compañia de Aguas del Aconquija SA and Vivendi Universal SA v Argentine Republic (ICSID case no ARB/97/3) (Annulment Proceeding) 10 August 2010.

61 See generally T Meshel, 'Human Rights in Investor-State Arbitration: The Human Right to Water and Beyond' (2015) 6 JIDS 277, and B Farrugia, 'The human right to water: defences to investment treaty obligations' (2015) 32 Arbitration International 1.

62 See above (n 58). Proceeding) 22 May 2014.

65 ICSID Rules of Procedure for Arbitration Proceedings (Arbitration Rules) (1986), Rules 32 and $37<\mathrm{http}$ ://scholarship.law.berkeley.edu/cgi/viewcontent.cgi? article=1059\&context=bjil $>$. 
implementation of this right through (among other things) the provision of clean drinking water. ${ }^{66}$

But, as explained, the derivation of the human right to water is far wider than the right to equality or the rights of the child. Domestic and international courts have also held that the right to life and the right to personal integrity, which entails a healthy environment, carry with them the right to adequate water. ${ }^{67}$

Development of the law by domestic courts feeds into the interpretation of human rights by supranational human rights courts and together they feed into, and inform, the development of international law. As regards the human right to water, the penny has now dropped with the international community.

The key instrument is the ICESCR. The ICESCR imposes an obligation on States to realize rights progressively, within the available means and resources of the State. And there is now an optional accountability mechanism for its enforcement. Until 2013, it was only possible to lodge communications at the international level regarding alleged violations of the ICESCR. Now Article 1 of a new Optional Protocol, ${ }^{68}$ which came into force in 2013, affirms that the Committee on Economic, Social and Cultural Rights ('the Committee'), which is tasked with the interpretation of the provisions of the ICESCR, is competent to receive and consider communications in accordance with the provisions that follow. Article 2 of the Optional Protocol provides that all rights set out in the ICESCR can be invoked before the Committee. Before individuals can bring complaints under this mechanism, they are required, amongst other things, to show that they have exhausted domestic remedies and that the same matter is not being examined under another procedure of international investigation or settlement. ${ }^{69}$ The Optional Protocol currently has 45 signatories and 21 parties. $^{70}$

The ICESCR does not explicitly mention a right to water. However, in General Comment No 15 ('GC 15'), issued in 2002, the Committee explicitly recognized that the right to water forms part of one of the rights guaranteed by the ICESCR, namely that contained in Article 11(1) of ICESCR. General Comments are not binding per se but they carry significant legal weight when the Committee has to interpret the ICESCR. These interpretations have significant bearing on the enforcement of the ICESCR, and the realization and observance of the ICESCR rights. Article 11(1) recognizes the right to an 'adequate standard of living'. It provides:

\footnotetext{
${ }^{66}$ Convention on the Rights of the Child (adopted 20 November 1989, entered into force 2 September 1990) 1577 UNTS 3.

67 See above, for example (n 23).

68 The Optional Protocol to the International Covenant on Economic, Social and Cultural Rights was adopted by the UN in 2008 and entered into force on 5 May 2013.

69 Article 3(2) of the Optional Protocol.

70 UN Treaty Collection, 'Optional Protocol to the International Covenant on Economic, Social and Cultural Rights' <https://treaties.un.org/Pages/ViewDetails.aspx?src=TREATY\&mtdsg_no= IV-3-a\&chapter=4\&lang=en>.
} 
The States Parties to the present Covenant recognize the right of everyone to an adequate standard of living for himself and his family, including adequate food, clothing and housing, and to the continuous improvement of living conditions. The States Parties will take appropriate steps to ensure the realization of this right, recognizing to this effect the essential importance of international cooperation based on free consent.

Importantly GC 15 calls on States to take steps to ensure the realization of this right. A State might act in response to GC 15 in a number of different ways. The State might seek to protect water sources, or in some circumstances to procure a supply of water or to provide information about water resources to communities affected. It would not be enough for the State to provide water that was deficient in quality or quantity. The water would have to be adequate in quantity, acceptable in quality, accessible and affordable. The reasons for this are selfevident.

GC 15 was a significant step, but matters did not stop there. In 2010, two resolutions further affirmed the existence of a right to water and confirmed its recognition in the international sphere. One was issued by the UN General Assembly and the other by its subsidiary the UN Human Rights Council ('HRC').

General Assembly Resolution 64/292 was adopted on 28 July $2010 .^{71}$ The resolution was called for by Bolivia. This resolution 'recognizes the right to safe and clean drinking water and sanitation as a human right that is essential for the full enjoyment of life and all human rights'. ${ }^{72}$ It also acknowledged the importance of equitable access to safe water and sanitation as an 'integral component of the realisation of all human rights'. It called upon States and international organizations to provide financial, capacity-building, and technological resources to developing countries as part of global efforts to provide 'safe, clean, accessible and affordable drinking water and sanitation for all'. ${ }^{73}$

HRC Resolution 15/9 was adopted on 30 September 2010. This affirmed that the human right to safe drinking water and sanitation was 'derived from the right to an adequate standard of living and inextricably related to the right to the highest attainable standard of physical and mental health, as well as the right to life and human dignity'. Most importantly it called on States:

... to develop appropriate tools and mechanisms, which may encompass legislation, comprehensive plans and strategies for the sector, including financial ones, to achieve progressively the full realisation of human rights obligations related to access to safe drinking water and sanitation, including currently unserved and underserved areas. ${ }^{74}$

${ }^{71}$ UNGA ‘The Human Right to Water and Sanitation' UN Doc A/RES/64/292 (3 August 2010).

72 ibid.

${ }^{74} \mathrm{HRC}$ 'Human rights and access to safe drinking water and sanitation' UN Doc A/HRC/RES/ 15/9 (6 October 2010). 
This refers to progressive realization, and so uses the language of a socioeconomic right. This is important because full realization depends on a State's resources. Nonetheless, it may well incorporate a minimum core obligation that has in general to be fulfilled immediately. The need for water is rather more pressing than many other needs and so it surely cannot be the case that a State could refuse to provide any water on the grounds that its resources do not permit it to do so.

Neither the resolution of the General Assembly nor that of the HRC is legally binding. Nonetheless, their adoption reflects an international trend in the recognition of a human right to water. The HRC Resolution bolsters GC 15's claim that the right to water derives primarily from Article 11 ICESCR.

What would be helpful is recognition of the right to water in customary international law. Customary international law depends on a consensus of States, which is only capable of proof by evidence of usage to be obtained from the action of nations in similar cases in the course of their history. It is important to ask if the right to water is part of customary international law because it would mean that States could be bound by the right even if they had not ratified the ICESCR or any human rights treaty which recognizes such a right. ${ }^{75}$ Because customary international law is uncodified, the courts are entitled to look at a broad range of sources when determining what the law is on a particular issue. ${ }^{76}$ Those sources could include: decisions of the International Court of Justice; UN material, such as resolutions and declarations of the General Assembly; declarations and publications of State departments; and decisions of national courts and historical records. The courts may attach different weight to different sources. In this case, General Assembly Resolution 64/292 received 122 votes in favour, with only 41 abstentions and no votes against. Twenty-nine States were absent. So while it was not passed by all UN members, there was no opposition to it. Furthermore, the wording is important: it states that the Assembly 'recognizes' the right to water, which is tantamount to acknowledging an existing right rather than creating a new right. ${ }^{77}$ The same approach was adopted by the Human Rights Council. ${ }^{78}$

Furthermore, in 2004 the International Law Association ('ILA') issued its Berlin Rules on Water Resources Law. ${ }^{79}$ These confidently state that following General Comment 15 there cannot be much doubt about the existence of the right to water. ${ }^{80}$ These 'Berlin Rules' may, however, place too much significance on human rights instruments rather than the traditional sources of customary international law. Even so, the issue of the General

\footnotetext{
75 See generally North Sea Continental Shelf cases [1969] ICJ Rep 41 at [71].

76 See the text of the draft conclusions provisionally adopted by the Drafting Committee of the International Law Commission at its 68th session (30 May 2016) on Identification of customary international law. $\quad{ }_{77}^{7}$ See above (n 72). $\quad{ }^{78}$ See above (n 74).

79 ILA 'Berlin Rules on Water Resources Law', Report on the 71st Conference (London, International Law Association, 2004) 334 and 336.
} 
Assembly Resolution 64/292 and GC 15 may indicate that the recognition of the right to water is not far away. This is especially so in the light of subsequent developments.

At first sight, it might seem as if thinking concerning the right to water reached a climax in the 2010 General Assembly and HRC resolutions, and nothing much had happened since. However, in September 2015, the General Assembly adopted the 2030 Agenda for Sustainable Development. ${ }^{81}$ This marks a major step forward in the development of the right to water. The 2030 Agenda for Sustainable Development takes forward, builds on and recasts the Millennium Development Goals, as it includes the new Sustainable Development Goals. ${ }^{82}$ These include the right to water and sanitation as a stand-alone goal. Goal Number Six acknowledges the risk that within the next 30 years one in four people is likely to live in a country affected by chronic or recurring shortages of fresh water.

It then sets out eight water-related targets to be achieved by 2030 which explicate what the human right to water may ultimately involve:

- achieve universal and equitable access to safe and affordable drinking water for all.

- achieve access to adequate and equitable sanitation and hygiene for all and end open defecation, paying special attention to the needs of women and girls and those in vulnerable situations.

- improve water quality by reducing pollution, eliminating dumping and minimising release of hazardous chemicals and materials, halving the proportion of untreated wastewater and substantially increasing recycling and safe reuse globally.

- substantially increase water-use efficiency across all sectors and ensure sustainable withdrawals and supply of freshwater to address water scarcity and substantially reduce the number of people suffering from water scarcity.

- implement integrated water resources management at all levels, including through transboundary cooperation as appropriate.

- protect and restore water-related ecosystems, including mountains, forests, wetlands, rivers, aquifers and lakes.

- expand international cooperation and capacity-building support to developing countries in water- and sanitation-related activities and programmes, including water harvesting, desalination, water efficiency, wastewater treatment, recycling and reuse technologies.

- Support and strengthen the participation of local communities in improving water and sanitation management. ${ }^{83}$

81 UNGA 'Transforming our world: the 2030 Agenda for Sustainable Development' UN Doc A/ RES/70/1 (21 October 2015). $\quad{ }^{82}$ ibid. $\quad{ }^{83}$ ibid. 
In January 2016, the UN Secretary General and the President of the World Bank jointly announced their intention to form a new panel to mobilize urgent action towards the sustainable development goal for water and sanitation and related targets. ${ }^{84}$ This decision comes as an explicit attempt to address the forecast that water stress and water-related disasters in many countries will increase due to climate change, unless better policy decisions are taken. On the basis of the awareness, in the words of UN Secretary General Ban Ki-Moon, water is 'crucial to realizing the SDGs, which at their heart aim to eradicate poverty' ${ }^{85}$

\section{CONCLUSIONS}

Why has there been a rush to categorize the right to water as a human right? It would be wrong to debase the coinage of human rights law by having a human right to almost anything, but the right to water is surely a special case. Moreover, one can say at an abstract level that the human right to water is the paradigm universal right: the content of the human right to water must be the same for everyone, though the way it is realized in different countries will vary.

This article started by stating that human rights provide the obvious framework to use today. There are probably many reasons for having human rights but three stand out:

1. By analysing the law through the lens of human rights, the law can turn the focus to vulnerable individuals with the greatest need.

2. The narrative has moved from implying the right to water from other rights to seeing the right to water as a human right in and of itself. Rights are empowering. Since everyone has human rights, the human rights analysis is inclusive and enables everyone to speak up about his entitlement and to be heard. So the human rights analysis encourages and strengthens democratic society.

3. If water is viewed as a human right under law, it can be enforced through the UN human rights system. The UN system provides a means whereby defaulting States may be called to account. It also provides material on which regional and national courts can draw in order to find rights and remedies where people have been deprived of a decent minimum water ration.

The following conclusions can be drawn from the developments which have taken place in national and international law:

1. The developments in international law have undoubtedly been the result of the pioneering work of courts in countries such as India.

\footnotetext{
${ }^{84}$ World Bank, Press Release, 'United Nations, World Bank Group Launch High Level Panel on Water' (The World Bank, 21 January 2016) <http://www.worldbank.org/en/news/press-release/ 2016/01/21/united-nations-world-bank-group-launch-high-level-panel-on-water>.

85 ibid.
} 
2. The human right to water in international law is in bud and about to flower. In light of the 2030 Agenda for Sustainable Development, it seems likely that, with the growing recognition of the importance of the fair distribution of water, before very long the right to water will be recognized in international law. ${ }^{86}$

3. If that happens, then, following Judge Simma's line of reasoning, the right of water will also have an important impact on the conduct of States trying to effect major infrastructure changes and on the decisions of international lenders and investors.

4. Recognition of the human right to water could make a huge contribution in the settlement of international disputes and proper water management worldwide. Instead of fighting over water, the law should be developed to contribute to the proper distribution of water and help reduce the mismanagement of water and its pollution and contamination.

5. The human right to water could therefore be the start of a new world order. Its recognition could lead to a change of culture in countries where human life is under threat.

Each year we celebrate World Water Day. The world, we are told, should this year go blue to celebrate - people should wear blue, paint themselves blue or even whistle the Blues. Certainly the recent developments in the law on the human right to water have been real and momentous.

${ }^{86}$ See generally the Gabcikovo-Nagymaros case (Hungary/Slovakia) (Judgment) [1997] ICJ Rep 7, at 140. See also the separate opinion of Judge Weeramantry, who made reference to the inference of a right to the environment from the right to health and the right to life at [91] and [92]. 